\title{
REAKSI AGAMA DAN BUDAYA DALAM DIMENSI PERENCANAAN KEPEMIMPINAN DI DUNIA PENDIDIKAN
}

\author{
Sadari \\ Institut Agama Islam Shalahuddin Al-Ayyubi, Tambun-Bekasi \\ Email : arifahmikhan@gmail.com
}

\begin{abstract}
Abstrak
Agama yang bersumber dari Allah Swt, kemudian agama bereaksi menjadi kecerdasan spiritual dalam kehidupan masyarakat, kemudian dihidupkan dalam bentuk ritual ibadah. Selanjutnya ritual ibadah dalam beragama dipahami manusia sebagai salah satu aspek budaya. Dari situlah dimensi kepemimpinan akan terencana melalui pemahaman agama, terlebih bila dikaitkan dengan dunia pendidikan. Perbedaan agama dan budaya terlihat dari sebuah proses yang berbeda, agama dipahami dari proses vertikal, sedangkan budaya dipahami dari proses horizontal. Agama bersifat spiritual sedangkan budaya bersifat akal, sehingga menurut sistem sosial budaya manusia disebut al-Insan yang memiliki akal pikiran, mampu mengembangkan budaya yang berdampak luas terhadap kehidupan dan lingkungan di permukaan bumi. Kemampuan akal pikiran dapat dinyatakan juga sebagai kemampuan budaya, memiliki makna yang tinggi bagi manusia sebagai makhluk hidup. Aspek-aspek atau komponenkomponen materi seperti ruang, alam semesta, bangunan, pakaian, peralatan dan non-materi semisal pengetahuan, kepercayaan, nilai, sikap, makna, hirarki, agama, peranan, merupakan suatu sistem yang disebut sistem budaya.

Sistem budaya merupakan rangkaian hubungan komponenkomponen budaya sebagai ungkapan prilaku, perbuatan, dan tindakan manusia sebagai makhluk budaya. Namun demikian, dalam mekanisme budaya tersebut, tidak terpisahkan dari hubungan antara manusia sebagai makhluk sosial yang menghubungkan antar individu, antara individu dengan kelompok, dan antara kelompok dengan kelompok manusia lainnya. Di sini terbentuk suatu tatanan yang dikonsepkan sebagai sistem sosial. Sistem ini terbentuk, sebagai akibat hubungan sosial antar komponen-komponen.
\end{abstract}

Kata Kunci: Agama; Budaya; Kepemimpinan; Pendidikan 


\section{Pendahuluan}

Sejalan dengan kemajuan dalam berbagai bidang sebagai hasil pembangunan, bidang pendidikanpun mengalami perkembangan. Perkembangan dalam dunia pendidikan tidak terlepas dari dimensi kepemimpinan yang mana seorang pemimpin punya beragam orientasi. Seorang pemimpun juga merupakan sosok yang mumpuni dan mempunyai sekumpulan dari serangkaian kemampuan dan sifat-sifat kepribadian, termasuk di dalamnya kewibawaan, untuk menjadikan sebagai sarana dalam rangka meyakinkan yang dipimpinnya agar mereka mau dan dapat melaksanakan tugas-tugas yang dibebankan kepadanya dengan rela, penuh semangat, ada kegembiraan batin, serta merasa tidak terpaksa. ${ }^{1}$

Dalam artikel ini mencoba mempertajam sebuah pembahasan bahwa ketika seorang pemimpin mempunyai orientasi terhadap bidang yang dipimpinnya, maka seorang pemimpin ternyata tidak terlepas dari pengaruh agama dan budaya yang mengitarinya. Dengan kata lain seorang pemimpin selalu bertumpu pada perubahan dan perkembangan sosial atau realitas yang ada disekelilingnya dalam hal ini adalah agama dan budaya.

Agama merupakan sumber kekuatan spiritual yang bisa membangkitkan perubahan dan perkembangan masyarakatnya. Karena agama mampu memberikan pemaknaan hakiki dalam perkembangan historis dan konkritnya dalam realitas penganutnya. ${ }^{2}$ Sementara budaya merupakan tatanan pengetahuan, kepercayaan, nilai, sikap, makna, hirarki, agama, waktu, peranan, hubungan ruang, konsep alam semesta, objek-objek materi dan milik yang diperoleh sekelompok besar orang dari generasi ke generasi melalui usaha individu dan kelompok. ${ }^{3}$

Oleh karena itu secara mendetail artikel ini juga akan menjelaskan bahwa pola kepemimpinan lambat-laun akan mengalami pergeseran paradigma atau perubahan nilai orientasi pada kepemimpinannya dalam sistem dunia pendidikan.

Hal tersebut akibat adanya faktor-faktor yang mempengaruhinya, dari sekian banyak faktor yang mempengaruhi dimensi kepemimpinan pendidikan antara lain adalah faktor agama dan budaya. Untuk itu pembahasan dalam artikel ini akan diungkap menjadi tiga pembahasan antara lain tentang: (1) urgensi kepemimpinan pendidikan, (2) agama dan perubahan sosial, (3) budaya dan perubahan sosial.

\section{Pembahasan}

\section{A. Urgensitas Kepemimpinan dalam dunia Pendidikan}

Lembaga pendidikan membutuhkan seorang pemimpin. Sebab, pemimpin itulah sosok penggerak dan inspirator dalam merancang dan mengerjakan kegiatan. Pemimpin tidak hanya seorang manajer, ia juga harus seorang pembangun mental, moral dan spirit kepada jajaran bawahannya. Seorang pemimpin tidak hanya menggunakan aturan tertulis, sikap perilaku, sepak terjang, dan keteladanan tetapi melakukan agenda transformasi ke arah yang baik. ${ }^{4}$ 2010), 26

${ }^{1}$ Ngalim Purwanto, Administrasi dan Supervisi Pendidikan, cet. ke-2 (Bandung: PT. Remaja,

2 Ignas Kleden, "Agama dan Perubahan Sosial”, dalam LP3ES, Agama dan Tantangan Zaman: Pilihan Artikel Prisma 1975-1984, cet. ke-1 (Jakarta: LP3ES, 1985), 215.

${ }^{3}$ Richard E. Porter \& Lary A. Samoar dalam Deddy Mulyana, Jalaluddin Rakhmat, editor, Komunikasi Antar Budaya (Bandung: Remaja Rosdakarya, 2000), 18.

${ }^{4}$ Jamal Ma'mur Asmani, Manajemen Pengelolaan dan Kepemimpinan Pendidikan Profesional, cet. ke-1 (Ttp: Diva Press, 2009), 91. 
Pemimpin tidak boleh menganggap bawahannya objek eksploitasi, justru bawahannya dianggap teman dan mitra kerja. Jadi, tidak ada kewenanganwenangan, kezhaliman, dan ketidakadilan. Karena tanpa bawahan, pemimpin tidak ada artinya. Jika ada seseorang mematuhi perintah pemimpin kesadarannya, maka itulah pemimpin yang sukses. Namun, jika bawahan mematuhi perintah pimpinannya karena takut dimarahi dan dipecat, maka pemimpin seperti itu belum layak menjadi pemimpin. Karena, ia tidak bisa mendidik dan mengayomi anak buahnya, tapi sebaliknya, menakut-nakuti dan menambah beban psikologis yang mengganggu kinerja bawahan.

Untuk menjelaskan tentang dimensi kepemimpinan, artikel ini menjelaskan terlebih dahulu dari sudut mana seseorang memandang atau memahami hakiki kepemimpinan itu, dan selanjutnya dari sudut mana seseorang memandang atau memahami hakiki kepemimpinan itu, dan selanjutnya, berdasarkan pemahaman tersebut terlihat bagaimana ia membuat perumusan atau mendefinisikannya untuk itu, maka artikel ini akan menguraikan tentang konsep kepemimpian dan definisi kepemimpinannya.

1) Pengertian kepemimpinan

Kepemimpinannya ditinjau dari sejarah perkembangannya dapat dikemukakan disini adanya tiga konsep kepemimpinan, yaitu suatu konsep yang menganggap bahwa kepemimpinan merupakan suatu kemampuan yang berupa sifat-sifat yang dibawa sejak lahir yang ada pada diri seorang pemimpin. Menurut konsep ini kepemimpinan diartikan sebagai traits within the individual leader. Jadi seorang dapat menjadi pemimpin karena dlahirkan sebagai pemimpin dan bukan karena dibuat atau dididik untuk itu (leader were borned and not made).

Konsep ini merupakan konsep kepemimpinan yang paling tua dan paling lama dianut orang. Bahkan di dalam kehidupan masyarakat dewasa ini, konsep tersebut masih dapat dilihat dengan jelas. Masih banyak pandangan orang-orang terutama dalam masyarakat agraris-feodal yang beranggapan bahwa seseorang muncul diangkat sebagai pemimpin semata-mata karena itu dianggap memiliki sifat-sifat yang baik atau setidak-tidaknya memiliki potensi yang merupakan pembawaan atau bahkan keturunan, yang diharapkan dapat menjadi suri tauladan bagi orang-orang lain yang akan dipimpinnya.

2) Hakikat Pemimpin

Pada hakikatnya, pemimpin adalah seseorang yang mempunyai kemampuan untuk mempengaruhi perilaku orang lain di dalam kerjanya dengan menggunakan kekuasaan. Kekuasaan adalah kemampuan untuk mengarahkan dan mempengaruhi bawahan sehubungan dengan tugas-tugas yang harus dilaksanakannya. Menurut Stoner (1988), semakin banyak jumlah sumber kekuasaan yang tersedia bagi pemimpin, akan makin besar potensi kepemimpinan yang efektif. Jenis pemimpin ada bermacam-macam, ada pemimpin formal, yaitu terjadi karena pemimpin bersandar pada wewenang formal.

Ada pula pemimpin informal, yaitu terjadi karena pemimpin tanpa wewenang formal berhasil mempengaruhi perilaku orang lain. Sebagaimana yang sering diungkapkan para pakar kepemimpinan, kekuasaan itu bersumber pada imbalan, paksaan, keahlian, acuan, hukum, karisma/kekuatan pribadi. Berdasarkan itu, bawahan atau orang biasa menerima atau tidak menerima atas segala sesuatu yang harus dilakukan.

Berbagai pendekatan dalam memecahkan masalah kepemimpinan telah dilakukan. Pendekatan pertama, sifatnya memfokuskan pada karakteristik pribadi 
pemimpin. Pendekatan kedua, memfokuskan pada perilaku dalam hubungannya dengan bawahannya. Pendekatan ketiga, memfokuskan pada situasional kesesuaian antara perilaku pemimpin dengan karakteristik situasional. Pandangan situasi ini mengasumsikan bahwa kondisi menentukan efektivitas pemimpin yang bervariasi dari unit situasi, keterampilan dan harapan bawahan, organisasi, serta pengalaman masa lalu pemimpin dengan bawahan. ${ }^{5}$

Bila menajer memperhatikan motivasi para bawahan kemudian mengarahkan perilaku, etos, dan cara mereka agar positif terhadap pekerjaan, maka menejer bertindak sebagai pemimpin. Pemimpin seseorang yang berkewajiban mempengaruhi sekelompok orang yang terorganisasi untuk mencapai tujuannya. Dengan demikian, seorang menejer juga merupakan seorang pemimpin, meskipun seorang pemimpin tidak mesti menjadi manejer.

Seorang guru yang berpengaruh terhadap perilaku beberapa guru lain, misalnya dalam suatu sekolah adalah pemimpin organisasi informal dalam sekolah itu, tetapi ia bukan menejer.

Pemimpin yang baik adalah orang yang memiliki dan melaksanakan syaratsyarat sebagai berikut:

1. Memiliki kepribadian yang cocok melaksanakan tugas memimpin.

2. Memperhitungkan faktor situasi dalam melaksanakan kepemimpinan.

3. Melakukan transaksi antara dia sebagai pemimpin dengan orang-orang yang dipimpin, yaitu meng-usahakan suatu kesepakatan bersama.

Ada beberapa konsep yang bisa dikaitkan dengan kepemimpinan yang memperhitungkan situasi. Terdapat beberapa gaya kepemimpinan, yaitu kepemimpinan otoriter, kepemimpinan demokrasi, dan kepemimpinan membebaskan (laissez faire). Kepemimpinan otoriter cocok digunakan dalam keadaan kacau, misalnya para siswa/mahasiswa melanggar ketertiban/mengacau, dan tidak mau memperhatikan peringatan petugas pendidikan.

Kepemimpinan demokrasi dipakai dalam pertemuan-pertemuan untuk menghasilkan konsep tertentu. Sedangkan kepemimpinan membebaskan biasanya dipakai dalam kelompo-kelompok yang anggota-anggotanya terdiri dari para ahli yang sudah dipandang mampu melaksanakan tugas secara mandiri.

Kast (1974) yang mengutip Davis mengatakan kepribadian pemimpin yang baik harus memiliki inteligensi yang baik, lapang dada dan memiliki tangan sosial, memiliki motivasi intrinsik dan motivasi berprestasi, serta memiliki sikap antar hubungan manusiawi. Dengan kepribadian seperti ini dan ditambah dengan memperhitungkan situasi (termasuk motivasi para bawahan) untuk menyesuaikannya gaya kepemimpinan, maka transaksi atau mufakat akan mudah dicapai.

Dengan dengan demikian, dalam usaha meningkatkan kepemimpinan, para manejer hendaknya pertama-tama mengenal bermacam-macam situasi. Bersama dengan itu, para manejer juga perlu belajar bagaimana berkomunikasi dengan baik dalam rangka melakukan musyawarah untuk mendapatkan kesepakatan atau transaksi dengan para bawahan. Kemudian, mencocokkan tugas-tugas agar relatif tepat dengan motivasi setiap bawahan. Dalam mempelajari apa hal di atas, diharapkan secara perlahan-lahan kepribadian para menejer dapat meningkat menuju kepribadian pemimpin yang diinginkan.

\footnotetext{
${ }^{5}$ Nanang Fattah, Landasan Manajemen Pendidikan (Bandung: Rosda Karya, 2008), 88.
} 
Sehubungan dengan usaha meningkatkan efektivitas kepemimpinan dengan cara menyesuaikan situasi dan kebutuhan/motivasi para bawahan yang telah diutarakan di atas, Reddin (1970) mengemukakan beberapa gaya kepemimpinan yang efektif sebagai berikut:

1. Gaya kepemimpinan eksklusif

Yaitu pemimpin yang memperhatikan efektivitas, individualitas bawahan, dan kepentingan organisasi. Pemimpin ini bermotivasi tinggi, memperlakukan para bawahan sesuai dengan individualitasnya masing-masing, dan merupakan tim manajer (kepemimpinan tim).

2. Gaya kepemimpinan otokratik yang bijaksana

Yaitu pemimpin yang memperhatikan efektivitas dan kepentingan organisasi. Pemimpin ini paham betul dengan apa yang diinginkannya dan giat mengejarnya.

3. Gaya kepemimpinan pembina/pengembang yang menekankan efektivitas dan individu bawahan.

Pemimpin berusaha mengembangkan potensi setiap bawahannya.

4. Gaya kepemimpinan birokratik,

Yaitu pemimpin yang menekankan efektivitas atas dasar peraturan dan prosedur. Pemimpin sangat terikat kepada peraturan dan prosedur ini. Yang sering kali hanya efektif terhadap pelaksanaan peraturan dan prosedur, belum tentu efektif terhadap tujuan organisasi. ${ }^{6}$

Pemimpin ideal adalah pemimpin yang dapat berkomunikasi secara efektif dalam situasi apa pun dan bijaksana. Pemimpin yang dapat berkomunikasi secara efektif adalah seorang pemimpin yang mampu melakukan beberapa hal berikut:

1. Memberikan informasi yang update (fakta yang ada di lapangan) kepada seluruh bawahan dan koleganya secara terus-menerus.

2. Proaktif meminta umpan balik dari bawahan.

3. Memastikan adanya tindak lanjut atas masalah yang terjadi dalam suatu organisasi.

4. Selalu meng-update informasi yang dimiliki berdasarkan fakta yang terjadi di lapangan.

Sedangkan tipe pemimpin bijaksana adalah seorang pimimpin yang memiliki karakteristik berikut:

1. Memiliki rasa percaya diri dan dapat mengatakan bisa pada diri sendiri untuk dapat menyelesaikan suatu masalah.

2. Sensitif terhadap perasaan/emosi pihak lain/anak buah

3. Dapat menyelesaikan masalah dengan cepat yang menjadi tanggung jawabnya dan terbiasa mendisiplinkan diri untuk mencari solusi setiap masalah dan bersikap action oriented.

4. Berpikir ke depan dan selalu berpikir contingency plan, yaitu selalu mengembangkan pikiran dalam beberapa skenario untuk mengantisipasi kondisi yang akan terjadi.

5. Pikirkan selalu kenyamanan anggota organisasi dalam bekerja.

Sementara pemimpin yang bijaksana tidak disarankan melakukan beberapa hal, pertama, menutup-tutupi permasalahan, berbohong mengatakan sesuatu yang sifatnya misleading. Sebagai pemimpin, memang harus menyiapkan hal-hal yang

227.

${ }^{6}$ Made Pidarto, Manajemen Pendidikan Indonesia (Jakarta: Rineka Cipta, 2004), 223- 
bersifat confidential, namun hal yang sifatnya berkaitan dengan keamanan dan kesejahteraan harus disampaikan secara terbuka.

Kedua, menjanjikan sesuatu yang belum ada kejelasannya untuk direalisasikan. Ketiga, Menyalahkan pihak lain atau mencari kambing hitam atas terjadinya masalah.

Seni berkomunikasi dan bergaul menjadi salah satu kata kunci seorang pemimpin. Ia harus menampilkan karakter yang fleksibel, tenang, tegas, tidak terlalu tegang, sekali-kali humoris, dan akrab dengan bawahannya agar tercipta lingkungan kerja yang nyaman, tidak ada tekanan dan paksaan. Semua berjalan berdasarkan aturan main yang dihayati dengan kesadaran bersama untuk maju mengembangkan lembaga.

Walaupun begitu, dalam kegiatannya, seorang pemimpin harus memiliki kekuasaan untuk mengarahkan dan mempengaruhi bawahannya sehubungan dengan tugas-tugas yang harus dilaksanakan. Pada tahap pemberian tugas, pemimpin harus memberikan suatu arahan dan bimbingan yang jelas, agar bawahan dapat melaksanakan tugasnya dengan mudah dan hasil yang dicapai sesuai dengan tujuan yang telah ditentukan.

Dengan demikian, kepemimpinan mencakup distribusi kekuasaan yang tidak sama di antara pemimpin anggotanya. Pemimpin mempunyai wewenang untuk mengarahkan anggota dan juga dapat memberikan pengaruh. Dengan kata lain, para pemimpin hanya dapat memerintah bawahan apa yang harus dilakukan, tetapi juga dapat mempengaruhi bagaimana bawahan melaksanakan perintahnya. Sehingga, terjalin suatu hubungan sosial yang saling interaksi antara pemimpin dengan bawahan.

Ada hubungan timbal balik secara sinergis antara keduanya, karena samasama membutuhkan dan berjalan pada tujuan yang sama. Oleh sebab itu, pemimpin diharapkan memiliki kemampuan dalam menjalankan kepemimpinannya dengan efektif. Karena, jika seorang pemimpin tidak memiliki kemampuan untuk memimpin maka tujuan yang ingin dicapai tidak akan dapat dicapai secara maksimal.

3) Tipe-tipe Kepemimpinan

Tipe seorang pemimpin satu dengan lainnya berbeda-beda, sesuai dengan karakter dan kepribadian masing-masing. Masing-masing punya keistimewaan dan kelebihan yang tidak ada pada orang lain. Manusia memang makhluk unik, begitu juga dengan seorang pemimpin. Satu pemimpin dengan pemimpin lain tidak sama, mengingat gaya kemimpinannya pun berbeda. Masing-masing orang mempunyai gaya kepemimpinan yang berbeda dengan orang lain.

Tipe-tipe kepemimpinan menurut G.R.Terry sebagaimana dikutip oleh Maman Ukas, ada enam tipe:

1. Tipe kepemimpinan pribadi (personal leadership).

Dalam sistem kepemimpinan ini, segala sesuatu tindakan itu dilakukan dengan mengadakan kontak pribadi. Petunjuk itu dilakukan secara lisan atau langsung dilakukan secara pribadi oleh pemimpin yang bersangkutan.

2. Tipe kepemimpinan non pribadi (non personal leadership).

Segala sesuatu kebijaksanaan dilaksanakan melalui bawahan-bawahan atau media non pribadi baik rencana atau perintah juga penga-wasan.

3. Tipe kepemimpinan otoriter (authoritarian leadership). 
Pemimpin otoriter biasanya bekerja keras, sungguh-sungguh, teliti, dan tertib. Ia bekerja menurut peraturan-peraturan yang berlaku secara ketat dan instruksiinstruksinya harus ditaati.

4. Tipe kepemimpinan demokratis (democratic leadership).

Pemimpin yang demokratis menganggap dirinya sebagai bagian dari kelompoknya dan bersama-sama dengan kelompoknya berusaha bertanggung jawab atas terlaksananya tujuan bersama. Agar setiap anggota turut bertanggung jawab, maka seluruh anggota ikut serta dalam segala kegiatan, perencanaan, penyelenggaraan, pengawasan, dan penilaian. Setiap anggota dianggap sebagai potensi yang berharga dalam usaha pencapaian tujuan.

5. Tipe kepemimpinan paternalistik (paternalistic leadership).

Kepemimpinan ini dicirikan oleh suatu pengaruh yang bersifat kebapakan dalam hubungan pemimpin dan kelompok. Tujuannya adalah untuk melindungi dan memberikan arah seperti halnya seorang bapak kepada anaknya.

6. Tipe kepemimpinan menurut bakat (indigenous leadership).

Biasanya, kepemimpinan tipe ini timbul dari kelompok orang-orang informal, di mana mungkin mereka berlatih dengan adanya sistem kompetisi, sehingga bisa menimbulkan 'klik-klik' dari kelompok yang bersangkutan. Biasanya juga akan muncul pemimpin yang mempunyai kele-mahan di antara yang ada dalam kelompok tersebut menurut bidang keahliannya, di mana ia ikut berkecimpung.

Sedangkan menurut Kurt Lewin, tipe-tipe kepemimpinan ada tiga, yaitu:

1. Otokratis

Pemimpin yang bekerja keras, sungguh-sungguh, teliti dan tertib. Ia bekerja menurut yang berlaku dengan ketat dan instruksinya harus ditaati.

2. Demokratis

Pemimpin yang demokratis menganggap dirinya sebagai bagian dari kelompoknya dan bersama-sama dengan kelompoknya berusaha bertanggung jawab tentang pelaksanaan tujuanya. Agar setiap anggota turut serta dalam setiap kegiatan-kegiatan, perencanaan, penyelengga pengawasan dan penilaian. Setiap anggota dianggap sebagai potensi yang berharga dalam usaha pencapaian tujuan yang diinginkan.

3. Laissez-faire

Pemimpin yang bertipe demikian, segera menyerahkan sepenuhnya pada para bawahannya untuk menyelesaikan pekerjaan-pekerjaan yang menjadi tanggung jawabnya, setelah tujuan diterangkan kepadanya. Ia hanya akan menerima laporan-laporan hasilnya dengan tidak terlampau turut campur tangan atau tidak terlalu mau ambil inisiatif. Semua pekerjaan tergantung pada inisiatif dan prakarsa dari para bawahannya. Dengan demikian, ia dianggap cukup dapat memberikan kesempatan pada para bawahannya untuk bekerja bebas tanpa kekangan.

Berdasarkan pendapat di atas, pada kenyataannya, kepemimpinan yang otokratis, demokratis, dan laissez-faire, banyak diterapkan oleh para pemimpin di berbagai macam organisasi, yang salah satunya dalam bidang pendidikan.

Dengan melihat hal tersebut, maka pemimpin di bidang pendidikan diharapkan memiliki tipe kepemimpinan yang sesuai dengan harapan atau tujuan, baik itu dari bawahan maupun dari atasan yang lebih tinggi posisinya, yang akhirnya gaya atau tipe kepemimpinan yang dipakai oleh para pemimpin, terutama dalam bidang pendidikan benar-benar mencerminkan dirinya sebagai seorang pemimpin yang profesional, sekaligus memiliki ragam pendekatan. 
Sebagai sosok pemimpin pendekatan adalah suatu keniscayaan, terutama dalam memimpin Perguruan Tinggi Islam yang konsen pada kajian "Islamic studies". Pendekatan dilakukan sebagai wujud pencarian model pembelajaran dan perkuliahan studi keislaman yang komprehensif pada level Perguruan Tinggi, dimana produk olahan dan masukkan dipusatkan diperguruan tinggi baik di lingkungan Departemen Pendidikan Nasional, Departemen Agama maupun Perguruan Tinggi di lingungan Pesantren, sehingga akan berdampak pada world view mahasiswa sebagai pengguna jasa keilmuan saat mereka menimba ilmu dan akan membentuk pola pikir, pola interaksi sosial serta tatanan masyarakat baru pada satu, dua atau tiga dekade yang akan datang ketika satu persatu para alumni Perguruan Tinggi tersebut beraksi di tengah masyarakat. ${ }^{7}$

Dalam melaksanakan aktivitasnya, pemimpin dipengaruhi oleh berbagai macam faktor. Faktor-faktor tersebut sebagaimana dikemukakan oleh H. Jodeph (1981) adalah sebagai berikut:

1. Kepribadian (personality), pengalaman masa lalu, dan harapan pemimpin mencakup nilai-nilai, latar belakang, dan pengalamannya.

2. Harapan dan perilaku atasan.

3. Karakteristik, harapan, dan perilaku bawahan.

4. Kebutuhan tugas dan setiap tugas bawahan. Iklim dan kebijakan organisasi.

5. Harapan dan perilaku rekan

Berdasarkan faktor-faktor tersebut, jelaslah bahwa kesuksesan pemimpin dalam aktivitasnya dipengaruhi oleh faktor-faktor yang dapat menunjang berhasilnya suatu kepemimpinan. Oleh sebab itu, suatu tujuan akan tercapai apabila terjadi keharmonisan dalam hubungan atau interaksi yang baik, antara atasan dengan bawahan, di samping dipengaruhi oleh latar belakang pemimpin, seperti motivasi diri untuk berprestasi, kedewasaan, dan keleluasaan dalam hubungan sosial dengan sikap-sikap hubungan manusiawi.

Adapun peran yang harus dilakukan seorang pemimpin sebagaimana dikemukakan oleh M. Ngalim Purwanto adalah sebagai berikut:

1. Sebagai pelaksana (executive)

2. Sebagai perencana (planner)

3. Sebagai seorang ahli (expert)

4. Sebagai wakil kelompok dalam tindakannya ke luar (external group representative)

5. Sebagai pengawas hubungan antar anggota-anggota kelompok (controller of internal relationship)

6. Bertindak sebagai pemberi gambaran/pujian atau hukuman (purveyor of rewards and punishments)

7. Bertindak sebagai wasit dan penengah (arbitrator and mediator)

8. Merupakan bagian dari kelompok (exemplar)

9. Merupakan lambang dari pada kelompok (symbol of the group)

10. Pemegang tanggung jawab para anggota kelompok (surrogate for individual responsibility)

11. Sebagai pencipta/pemilik cita-cita (ideologist)

12. Bertindak sebagai seorang ayah (fatherfigure)

13. Sebagai kambing hitam (scapegoat)

7 M. Amin Abdullah, Islamic Studies di Perguruan Tinggi: Pendekatan IntegratifInterkonektif, cet. Ke-1 (Yogyakarta: Pustaka Pelajar, 2006), xi-xii. 
Berdasarkan peranan pemimpin tersebut, menjadi bahwa suatu kepemimpinan harus memiliki peranan yang dimaksud, di samping juga memiliki tugas yang diembannya, yaitu: pertama, menyelami kebutuhan-kebutuhan kelompok dan keinginan kelompoknya. Dari keinginan itu dapat dipetiknya kehendak-kehendak yang realistis dan yang benar-benar dapat dicapai. Kedua, meyakinkan kelompoknya mengenai apa-apa yang menjadi kehendak mereka, mana yang realistis dan mana yang sebenarnya merupakan khayalan.

Tugas pemimpin tersebut akan berhasil dengan baik apabila setiap pemimpin memahami tugas yang di dilaksanakannya. Oleh sebab itu, kepemimpinan akan tampak dalam proses di mana seseorang mengarahkan, membimbing, mempengaruhi, dan atau menguasai pikiran-pikiran, perasaanperasaan atau tingkah laku orang lain.

Untuk berhasil dalam pencapaian suatu tujuan, diperlukan seorang pemimpin yang profesional, yang mampu memahami tugas dan kewajibannya sebagai seorang pemimpin, melaksanakan peranannya sebagai seorang pemimpin.

Di samping itu, pemimpin juga harus menjalin hubungan kerja sama yang baik dengan bawahan, sehinggga tercipta suasana kerja yang membuat bawahan merasa aman, tenteram, dan memiliki suatu kebebasan dalam mengembangkan gagasannya untuk mencapai tujuan bersama yang telah ditetapkan.

Keterangan di atas memberikan gambaran jelas bahwa pemimpin mempunyai daya ubah yang dahsyat dalam menjalankan roda organisasi. Karena, dia tidak hanya berfungsi sebagai perencana, tapi juga executor, pelaksana kebijakan. Perencanaan dan pelaksanaan adalah dua hal yang mempengaruhi perubahan besar dalam pergumulan sosial kemasyarakatan.

Dengan organisasi yang dipimpinnya, seorang pemimpin mampu melakukan perubahan-perubahan fisik dan non-fisik kepada lembaganya dan masyarakat umum. Ia bisa menjadikan organisasi yang dipimpinnya sebagai sentral pemberdayaan masyarakat dalam semua aspek kehidupan.

Dalam konteks pendidikan, seorang pemimpin bisa melahirkan kebijakan yang progresif dan visioner. Ia juga mampu memastikan efektivitas dan produktivitas kebijakan yang diambil dengan parameter yang jelas. Ia akan selalu mendorong bawahan dan mitra kerjanya untuk memahami visi dan misi yang diterapkan, tidak sekadar formalitas kegiatan tanpa memahami spirit nilai yang ada di dalamnya.

Secara umum, kepemimpinan memiliki tiga unsur penting untuk dipahami, yaitu apa atau siapa yang dipimpin, pemimpin, dan pedomannya. Seseorang yang tidak memiliki pemahaman yang baik atas tiga unsur tersebut akan sulit baginya untuk mengatur suatu organisasi atau lembaga. Pemimpin yang baik akan berusaha tidak saja mempelajari pedoman-pedoman dalam memimpin, tetapi juga berani meluangkan waktunya untuk mempelajari apa atau siapa yang dipimpin. ${ }^{8}$

Pemimpin pendidikan tidak akan mentolerir kecurangan, distorsi, deviasi yang dilakukan oleh bawahannya, karena akan merusak reputasi personal dan lembaga. Ia akan membimbing dan mengarahkan jajarannya untuk jadi teladan yang baik bagi masyarakat, membebaskan pendidikan di negeri ini dari korupsi, kolusi, nepotisme.

8 Sadari, et.al, "Reorientasi Nila-Nilai Kepemimpinan Lembaga Pendidikan Islam Muhammadiyah di Indonesia, dalam Fuaduna: Jurnal Kajian Keagamaan dan Kemasyarakatan, published by Institut Agama Islam Negeri (IAIN) Bukitinggi, Vol.03.No.1, 2019, 1. 
Semua berjalan di atas rel yang benar, ada kecurangan, diskriminasi, dan marginalisasi kelompok. Semua dianggap bagian dari bangsa yang harus dilayani dengan baik.

Menghadapi tantangan dunia yang cepat berubah, seorang pemimpin pendidikan akan terus melakukan proses adaptasi, konsolidasi, dan ekspansi secara dinamis. Ia juga mendorong bawahannya untuk terus belajar memahami perubahan zaman dan menyiapkan langkah-langkah antisipasinya de

ngan baik. Seorang pemimpin harus dapat memberikan keteladanan dalam ikap, berperilaku, mengambil kebijakan, dan melaksanakannya. Kesungguhan, kerja keras, konsistensi dan komitmen menjadi cermin anak buah dan kerjanya. Jika hal tersebut benar-benar lahir dari jiwanya yang suci, maka itu akan menjadi daya ubah besar. Akan tetapi, jika hanya kamuflase, maka tinggal cerita, tidak ada daya ubah yang lahir dari sana.

Hati manusia yang suci bisa membedakan ketulusan dan kemunafikan. Dengan ketulusan, orang pemimpin akan dicintai dan diikuti perilakunya. Dan itulah fungsi transformasi yang dibutuhkan pemimpin dalam menggerakkan perubahan substansial terutama dalam membangun paradigma yang revolusioner dalam dunia kehidupan dan pembelajaran. ${ }^{9}$

\section{B. Pergeseran Nilai Agama dan Perubahan Sosial terhadap Pola Kepemimpinan}

Fenomena perubahan sosial dewasa ini menggambarkan dan menjelaskan kepada kita bahwa agama menjadi salah satu faktor perubahan sosial itu sendiri. Agama sebagai hasil kebudayaan, yang ada, hidup dan berkembang dalam masyarakat memiliki peranan penting dalam perubahan sosial tersebut. Perubahan sosial yang terjadi dalam masyarakat merupakan hal yang tidak bisa terlepas dari keterikatannya dengan adanya agama.

Dalam hal ini, menggagas pemikiran tentang hubungan antara agama dan perubahan sosial bertitik-tolak dari pengandaian bahwa perubahan sosial merupakan suatu fakta yang sedang berlangsung, yang diakibatkan oleh kekuatankekuatan yang sebagian besar berada diluar kontrol kita, bahwa tidak ada kemungkinan sedikitpun untuk menghentikannya. Di sini, disposisi agama, pada satu sisi dapat menjadi penentang perubahan dan pada sisi lain dapat menjadi pendorong adanya perubahan sosial.

Perubahan sosial dalam masyarakat atau komunitas manusia tertentu dapat berakibat atau berdampak positif maupun negatif. Kenyataan perubahan itulah yang kemudian menarik minat para pemikir dan pengamat sosial untuk merumuskan dan menjelaskan mengapa hal tersebut sampai bisa terjadi. Uraian berikut ini merupakan suatu bentuk pemaparan yang mencoba menelaah dan mendalami pandangan Karl Marx dan Emile Durkheim tentang agama dalam kaitannya dengan perubahan sosial yang terjadi di dalam masyarakat.

1) Agama dan Masyarakat

Keberadaan agama atau kepercayaan tidak dapat dilepaskan dari kehidupan masyarakat. Manusia pada awalnya menyadari bahwa ada kekuatan yang

${ }^{9}$ Paradigma Titik Ba adalah sebuah tawaran paradigma revolusioner tentang bagaimana menghayati dan menjelajahi kehidupan dan pembelajaran sepanjang hayat secara utuh, bermaka dan ikhlas, lihat, Ahmad Thoha Faz, Titik Ba: Paradigma Revolusioner dalam Kehidupan dan Pembelajaran, cet. Ke-1 (Bandung: PT Mizan Pustaka, 2007). 
melampaui kekuatan yang ada pada dirinya. Karenanya manusia mulai menyembah dewa-dewa; animisme dan dinamisme mulai berkembang. Bersamaan dengan kesadaran dan tindakan penyembahan ini, manusia lalu menciptakan agama dan secara serentak pula bersamaan mereka menciptakan karya-karya seni.

Kesadaran diri sebagai manusia jelas tidak dapat dilepaskan dari adanya manusia lain di luar dirinya yang kemudian membentuk masyarakat atau kelompok manusia. Seorang individu menyadari dirinya sebagai manusia ketika ia mengalami manusia lain yang ada di luar dirinya.

Karya seni, juga agama, adalah hasil dari proses kreatif-produktif masyarakat melalui pengembangan kemampuannya sebagai mahluk rasional (homo sapiens) tetapi sekaligus manusia spiritual (homo religius).

Agama sebagai kepercayaan kolektif dapat dikatakan terbentuk setelah adanya masyarakat. Agama tidak dapat dipandang sebagai kepercayaan individu belaka yang berusaha mengenali kekuatan di luar dirinya lepas dari masyarakat. Pokok tersebut menjadi jelas bahwa agama dapat dibedakan dari kepercayaan pribadi dalam hal sifat sosial-kolektif yang dimilikinya. Agama dalam pengertian inilah yang hendak dihubungkan dengan masyarakat.

Masyarakat muncul ketika ada pergeseran cara hidup manusia dari nomaden menjadi manusia menetap, dari berburu dan meramu untuk memenuhi kebutuhan hidup menjadi bercocok tanam. Saat itulah manusia mulai berkelompok dan menemukan dirinya berada dalam ketegangan antara kepentingannya dengan kepentingan orang lain dalam kelompok itu.

Di satu sisi masyarakat yang terbentuk itu mendorong terbentuknya peradaban manusia yang mengangkat harkat dan martabatnya sebagai makhluk berakal budi ke tingkat yang lebih tinggi. ${ }^{10}$ Akan tetapi di sisi lain, masyarakat yang terbentuk itu membawa dampak negatif berupa persaingan sumber daya alam yang berfungsi vital demi kelangsungan hidup bangsa manusia itu sendiri, lebih khusus lagi bagi kelompoknya masing-masing.

Dua macam dampak kemunculan masyarakat ini dapat menjadi kunci kepada dua corak teori asal-usul agama. Sosiolog seperti Robertson Smith dan Emile Durkheim memandang kemunculan agama secara positif sejalan dengan perkembangan masyarakat. Agama bagi mereka bukanlah persoalan individu melainkan representasi kolektif dari masyarakat. Mereka menekankan bahwa agama pertama-tama adalah aksi bersama dari masyarakat dalam bentuk ritualritual, upacara keagamaan, larangan-larangan praktis dari pada keimanan.

Dengan demikian dapat dikatakan bahwa masyarakat secara positif berperan dalam terbentuknya atau munculnya agama. Di lain pihak pemikir seperti Marx memandang kemunculan agama sebagai reaksi manusia atas keadaan masyarakat yang 'rusak'. Kenyataan masyarakat yang terbagi dalam kelas-kelas sosial mendorong sekelompok orang dari kelas yang tertindas untuk melarikan diri dari keadaan struktural masyarakat yang represif dan kemudian melarikan impian dan harapannya kepada agama. Agama adalah “...usaha manusia untuk

${ }^{10}$ Secara linguistik dibedakan Istilah basar dengan insan, bahwasannya basar adalah jenis mahluk hidup yang tidak berakal pikiran, sedangkan Insan adalah manusia yang sudah memiliki akal pikiran, berbahasa, berbudaya, dan berkarakter mulia, lihat, Abdus Shabur Syahin, Penciptaan Nabi Adam Mitos atau Realitas, terj. Abii Adam, Qishshah al-Khaliiqah, cet. Ke-1 (Yogyakarta : eLSAQ PRESS, 2004), v-vi. 
menemukan makna dan arti kehidupan, di tengah derita yang menimpa wujud kasadnya."

Keterkaitan yang demikian erat antara agama dan masyarakat ini berdampak pada pemanfaatan fungsi kolektif agama untuk menggerakkan masyarakat demi perubahan sosial atau juga demi tujuan tertentu yang entah menguntungkan atau merugikan masyarakat itu sendiri.

2) Relasi Agama dan Perubahan Sosial perspektif Karl Marx dan Emile Durkheim

a) Perspektif Karl Marx

Dalam kerangka memahami dan menganalisa hubungan antara agama dan perubahan sosial, menurut Karl Marx, maka terlebih dahulu perlulah melihat garis besar gagasan dan pandangannya tentang agama.

1. Agama Sebagai Alat Penindasan

Pemahaman terhadap pemikiran Marx mau tidak mau perlu memahami dan mengikuti pemikirannya dan memasukkan agama ke dalam suatu kerangka kehidupan bermasyarakat. Marx memang bahwa agama hanyalah merupakan suatu gejala sosial yang berupaya meyakinkan masyarakat kelas bawah yang kemudian berdampak pada kelanggengan kekuasaan kelas atas atau kelompok yang berkuasa.

Dengan jelas ia katakan bahwa "agama adalah candu rakyat." Pernyataan Marx ini menyatakan dan memuat suatu serta sering diartikan sebagai tuduhan bahwa agama dengan menjanjikan kebahagiaan di alam sesudah kematian, di dunia lain dari kehidupan manusia, membuat orang miskin dan tertindas semakin tertindas serta menerima nasib mereka daripada memberontak terhadapnya. Kenyataan yang demikian dengan jelas menggambarkan suatu warna atau gejala ketertindasan.

Penindasan yang dipahami oleh Marx adalah suatu perilaku eksploitatifekonomistik, di mana manusia dijadikan objek yang bisa dimanfaatkan untuk kepentingan tertentu. Marx yakin bahwa orang jatuh dalam kemiskinan karena tindakan-tindakan penindasan "kelas atas, para pemilik modal" terhadap mereka yang dikategorikan dalam "kelas bawah, para buruh".

Agama pada titik ini dijadikan sebagai tempat perlindungan yang aman bagi penguasa untuk melanggengkan kekuasaan mereka; agama menjadi instrumen kekuasaan. Dengan kata lain, kemiskinan itu disebabkan oleh struktur-struktur ekonomi masyarakat yang menindas, yang diciptakan oleh para kapitalis demi memperbesar modal mereka.

Berhadapan dengan struktur-struktur yang menindas dan pemiskinan itu, orang tidak bisa berbuat lain kecuali pasrah dan akhirnya bersimpuh di hadapan Tuhan yang diciptakannya sendiri. Inilah yang disebut oleh Marx sebagai alienasi bahwa dalam agama alienasi itu terjadi karena manusia tunduk dan berada di bawah entitas suci yang diciptakannya sendiri. Dengan menciptakan Tuhan, dengan sendirinya manusia merendahkan martabatnya sendiri sehingga ia semakin asing dengan dirinya sendiri. Dengan demikian, agama tidak lain adalah instrumen penindas yang diciptakan manusia sendiri.

Berangkat dari perihal di atas, Marx kemudian menjelaskan bagaimana usaha agama untuk melestarikan diri. Agar tetap eksis, agama akan melanggengkan kemiskinan, kesengsaraan, dan perbudakan. Sehingga baginya agama hanya akan berakhir ketika kondisi-kondisi yang diperlukan untuk survive-nya kesengsaraan, kekuasaan kelas, eksploitasi komoditas, dihilangkan. 
Lalu muncul pertanyaan mengapa setiap masyarakat mempunyai agama? Tanggapan Marx bahwa agama mendukung dan melayani kepentingan tertentu yang terkait dengan dominasi kelas dan penundukan kelas. Dia menyebutkan bahwa agama dari sudut sosialitasnya adalah rengekan golongan masyarakat yang tertindas.

2. Agama dan keterasingan Manusia

Marx sendiri meyakini bahwa masyarakat kapitalistik memang menawarkan terjadinya realisasi diri manusia, tetapi hal itu hanya terjadi bagi segelintir orang dan bukan bagi seluruh masyarakat.

Marx kemudian menawarkan apa yang disebut dengan masyarakat komunis bahwa dalam masyarakat komunis setiap inidividu akan menikmati kehidupan yang aktif, kaya, dan bermakna; kendati hal itu berkait dengan hidup bersama, akan tetapi realisasi diri tetap dimungkinkan. Marx juga mengatakan bahwa dalam agama tidak ada bentuk realisasi diri yang sesungguhnya. Hal itu terjadi karena di dalam agama, manusia hanya boleh tunduk dan tidak terbuka bagi dialog yang memberikan kemungkinan bagi setiap individu untuk mengekspresikan dirinya. Agama tidak mengembangkan jati diri manusia secara utuh, karena manusia hanya tergantung pada otoritas semu yang diciptakannya sendiri. Menurut Marx, agama yang hanya mampu menghukum pemeluknya adalah agama ciptaan kaum kapitalis untuk menindas orang-orang kecil dengan doktrin-doktrin kesalehan. Di dalam doktrin itu orang diharuskan hidup saleh dengan 'olah tapa' yang berat dan menerima penderitaan dengan sukarela agar dapat memperoleh kemenangan di surga.

Pada titik ini, Marx melihat bahwa hal tersebut hanya merupakan ciptaan masyarakat, ciptaan penguasa, untuk memperkuat hegemoni dan melanggengkan kekuasaannya terhadap masyarakat kecil yang dipimpinnya. Dengan demikian menjadi jelas bahwa bagi Marx, dalam tindakan serta praksis keagamaan semacam itu memungkinkan orang tergantung pada ciptaannya sendiri. Manusia tidak lagi otonom. Manusia dalam agama hanyalah orangorang yang takluk di bawah otoritas orang yang lebih berkuasa daripadanya. Lepas dari kritik terhadap gagasan Marx, dalam analisis artikel ini bahwa teori Marx tentang masih mengandung kegunaan. Salah satu kegunaannya teori Marx adalah berguna untuk menganalisa masyarakat Eropah dan berguna menganalisa bentuk-bentuk masyarakat lain, termasuk masyarakat Timur. ${ }^{11}$ Meskipun gagasan Marx tentang agama sebagai proyeksi manusia belaka, terletak pada sifat menghibur, menyemangati dan memotivasi yang ada pada agama.

Menurut Marx, agama adalah proyeksi manusia yang mencari penghiburan dari kenyataan hidup yang represif maka dapat dikatakan agama sebagai tempat pelarian itu bersifat menghibur dan menyemangati kembali manusia yang mengalami keterpurukan nasib, bahkan andaipun penghiburan itu hanya ilusi dan tidak nyata.

Misalnya gerakan keagamaan di India. Gerakan keagamaan yang terjadi di India pada masa pra penjajahan Inggris dan pasca penjajahan Inggris merupakan perwujudan dari protes masyarakat kasta rendah atas ketidakadilan struktural yang disebabkan oleh sistem kasta. Gerakan keagamaan yang

\footnotetext{
${ }^{11}$ Mohammad Hatta, Ajaran Marx atau Kepintaran Sang Murid Membeo, cet. ke-1 (Jakarta: Bulan Bintang, 1975), 9.
} 
menuntut perubahan keadaan, khususnya terhadap sistem kasta, muncul sebagai penyimpulan artikulasi kepentingan kelompok kasta rendah yang menghendaki kesetaraan status sosial. Keadaan mayoritas masyarakat yang direpresi oleh elit kecil dalam masyarakat mendorong mayoritas masyarakat untuk 'melarikan diri' dalam gerakan keagamaan yang menghibur dan memberi harapan.

Akan tetapi tidak seperti teori Marx. 'pelarian ke dalam agama' tersebut tidak memperlemah masyarakat India pada waktu itu untuk menghadapi kenyataan hidup yang pahit. Pelarian pada agama justru menguatkan mereka untuk berjuang. Inilah kekecualian yang tidak dilihat oleh Marx dalam teorinya.

Dengan demikian dapatlah dikatakan bahwa agama di satu sisi, agama menurut analisa Marx, dapat secara terus menerus 'mengamankan' kelompok masyarakat kelas atas dan tidak mendatangkan perubahan sosial, sebab agama hanya melanggengkan kekuasaan masyarakat kelas atas. Dapatlah dikatakan bahwa dalam agama yang terus 'menidurkan' masyarakat kelas bawah tidak akan terjadi perubahan sosial. Jelasnya bahwa, yang dituntut atau yang menandakan adanya perubahan sosial adalah suatu kondisi kehidupan masyarakat di mana ada kesetaraan dan perubahan nasib serta tatanan hidup para anggotanya.

Sementara itu, di sisi lain, struktur yang dibentuk oleh agama dapat pula melahirkan kesadaran akan ketertindasan dan memunculkan gerakan untuk memberontak atau melakukan perubahan terhadap struktur masyarakat yang tidak adil. Pendobrakan terhadap struktur dan tatanan masyarakat yang telah 'mantap' di tangan para penguasa memungkinkan suatu perubahan sosial.

Tidak hanya itu, pandangan Marx yang menyatakan bahwa agama melanggengkan hegemoni kelas atas memiliki kelemahan. Fenomen yang ada dan justru terjadi dewasa ini adalah bahwa orang yang beragama turut berpatisipasi dan terjun langsung ke lapangan dan secara bersama berupaya menyelesaikan segala persoalan yang dihadapi masyarakat.

Agama sungguh menjadi suatu realitas sosial, yang hidup dalam dunia nyata manusia, dan bersama dengan pemeluknya bergelut dengan kemelut nyata kemasyarakatan. Maksudnya bahwa agama sungguh berpijak pada dunia nyata, dengan kompleksitasnya. Di situlah agama tampil sebagai instrumen pembebasan dan bukan sebagai bagian dari penindasan yang mempermiskin dan mengasingkan manusia dari diri dan dunia nyatanya.

Anggapan bahwa agama dapat menjadi salah satu faktor yang memicu konflik dalam masyarakat ala Marx tidak seluruhnya benar, sebab pada dasarnya agama mengajarkan dan mewartakan perdamaian, kehidupan yang harmonis demi kebaikan bersama. Oleh karena itu Ali Syari'ati sangat mengkritik keras pemikiran Karl Marks yang menyangkal dimensi transendental dari eksistensi manusiawinya. ${ }^{12}$

Ini berarti bahwa agama memberikan sumbangan besar bagi masyarakat yang memungkinkan masyarakat tersebut dapat hidup secara baik serta berkembang dalam kedamaian. Dengan demikian, bila penghayatan ajaran agama dijalankan secara baik dan benar maka konflik maupun pertentangan sedapat mungkin dihindari dan tidak mungkin terjadi. Lebih dari itu, kebenaran

${ }^{12}$ Ali Syari'ati, Kritik Islam atas Marxisme dan Sesat Pikir Barat Lainnya, terj. Marxism and Other Western Fallacies, cet. ke-1 (Bandung: Mizan, 1983), 75. 
yang diajarkan agama mendapat tempat perwujudan ajarannya pada dunia masyarakat yang nyata.

Agama berupaya untuk menerjemahkan pandangannya dalam masyarakat yang nyata. Dari sinilah kesetaraan dan keharmonisan dapat terjadi asalkan para penganutnya mau dan setia melaksanakan ajaran agama dengan baik dan benar. Sehingga agama bukanlah menjadi instrumen penindas, alat pelanggeng kekuasaan, melainkan sebagai lembaga yang membangun dan menghidupkan masyarakat bersama menuju tercapainya tujuan bersama suatu kelompok masyarakat (bonum commune).

b) Perspektif Emile Durkheim

Menurut Emile Durkheim ${ }^{13}$, didefinisikan sebagai suatu "sistem kepercayaan dan praktek yang telah dipersatukan yang berkaitan dengan halhal yang kudus, kepercayaan-kepercayaan dan praktek-praktek yang bersatu menjadi suatu komunitas moral yang tunggal." Definisi ini menyiratkan dua unsur yang penting, yang menjadi syarat adanya agama. Prasyarat itu adalah "sifat kudus" agama dan "praktek-praktek ritual" agama. Bertitik tolak dari pengertian atau pengertian yang dikatakan sebelumnya, agama dengan demikian tidak serta merta melibatkan konsep adanya suatu makhluk supranatural. Pada titik ini dapat kita lihat bahwa agama bukan semata-mata ditilik dari substansi isinya, melainkan dari bentuknya, yang melibatkan cirinya yang bersifat kudus dan yang terungkapkan dalam "praktek-praktek ritual" agama. Durkheim juga melihat agama sebagai sesuatu yang selalu memiliki hubungan dengan masyarakatnya, dan memiliki sifat yang historis.

1. 'Sifat Kudus' Agama

'Sifat kudus' yang dimaksud Durkheim dalam kaitannya dengan pembahasan agama tidak dalam artinya yang bersifat teologis, melainkan sosiologis. Sifat kudus itu dapat diartikan sebagai sesuatu yang "kudus" itu "dikelilingi oleh ketentuan-ketentuan tata cara keagamaan dan laranganlarangan, yang memaksakan pemisahan radikal dari yang duniawi." Sifat kudus ini dibayangkan sebagai suatu kesatuan yang berada di atas segala-galanya. Durkheim menyambungkan lahirnya pengkudusan ini dengan perkembangan masyarakat. Durkheim kemudian menjelaskan fenomena totemisme untuk menjelaskan fenomen keagamaan. Di dalam totemisme, ada tiga obyek yang dianggap kudus, yaitu totem, lambang totem dan para anggota suku itu sendiri. Pada totemisme Australia, benda-benda yang berada di dalam alam semesta dianggap sebagai bagian dari kelompok totem tertentu, sehingga memiliki tempat tertentu di dalam organisasi masyarakat.

Karena itu semua benda di dalam totemisme Australia memiliki sifat yang kudus. Totemisme Australia tidak memisahkan secara jelas antara obyekobyek totem dengan kekuatan kudusnya. Lain halnya dengan totemisme di Amerika Utara dan Melanesia. Di wilayah ini, kekuatan kudus itu jelas terlihat berbeda dari obyek-obyek totemnya, dan disebut berdasarkan nama yang disematkan padanya.

${ }^{13}$ Emile Durkheim (1858-1917) adalah sosiologi Perancis yang berjasa melembagakan sosiologi sebagai suatu disiplin kajian akademik, dua karya penting yang banyak dirujuk adalah The Rules of Sociological Method (1895) dan Suicede (1897), idenya tentang Integrasi sosial dam solidaritas sosial. lihat, Syarifuddin Jurdi, Sosiologi Islam \& Masyarakat Modern: Teori, Fakta dan Aksi Sosial, cet. ke-2 (Jakarta: Kencana Prenadamedia Group, 2014), 24. 
Totemisme yang ada pada masyarakat tertentu, oleh Durkheim, dikembangkan dan dijadikan suatu titik pijak untuk menjelaskan fenomena moralitas yang ada dalam masyarakat. Ia menyatakan bahwa 'sifat kudus' itu juga terdapat dalam aturan moral. Sebuah aturan moral hanya bisa hidup apabila ia memiliki sifat "kudus", sehingga setiap upaya untuk menghilangkan sifat "kudus" dari moralitas akan menjurus kepada penolakan dari setiap bentuk moral. Dengan demikian, "kekudusan"-pun merupakan prasyarat bagi suatu aturan moral untuk dapat hidup di dalam masyarakat. Hal tersebut menunjukkan bahwa "kekudusan" suatu obyek tidak tergantung dari sifat-sifat obyek itu an sich, tetapi tergantung dari pemberian sifat "kudus" itu oleh masyarakatnya.

2. Ritual Agama

Agama juga selalu melibatkan ritual tertentu. Praktek ritual ini ditentukan oleh suatu bentuk lembaga yang pasti. Ada dua jenis praktek ritual yang terjalin dengan sangat erat satu sama lain. Pertama, praktek ritual yang negatif, yang berwujud dalam bentuk pantangan-pantangan atau laranganlarangan dalam suatu upacara keagamaan. Praktek-praktek ritual yang negatif itu memiliki fungsi untuk tetap membatasi antara yang kudus dan yang duniawi. Pemisahan ini menjadi dasar dari eksistensi "kekudusan" itu. Praktek tersebut menjamin agar kedua dunia, yaitu yang "kudus" dan yang "profan" tidak saling mengganggu atau menekan satu sama lain. Contohnya adalah liburan pada hari raya besar keagamaan tertentu. Kedua, praktek ritual yang positif. Hal ini berwujud dalam bentuk upacara-upacara keagamaan itu sendiri dan merupakan intinya. Adapun praktek-praktek ritual yang positif-yang adalah upacara keagamaan itu sendiri-, berupaya menyatukan diri dengan keimanan secara lebih khusuk, dan dengan demikian berfungsi untuk memperbaharui tanggungjawab seseorang terhadap ideal-ideal keagamaan.

3. Fungsi Agama

Teori keagamaan Durkheim menyatakan fungsi agama sebagai pemersatu masyarakat. Agama bagi Durkheim adalah sebuah kekuatan kolektif dari masyarakat yang mengatasi individu-individu dalam masyarakat. Setiap individu, sebaliknya, merepresentasikan masyarakat dalam agama, yaitu melalui ketaatan kepada aturan-aturan keagamaan, misalnya dengan menjalankan ritual-ritual keagamaan. Agama, dengan demikian, menjadi tempat bersatunya individu-individu, bahkan ketika terjadi banyak perbedaan antara individu karena agama sebagai kekuatan kolektif masyarakat bersifat mengatasi kekuatan-kekuatan individual. Selain itu, agama juga turut menjawab masalah, persoalan dan kebutuhan hidup pribadi atau individu tertentu. Dalam agama, individu merasa dikuatkan dalam menghadapi derita, frustrasi, dan kemalangan. Melalui upacara keagamaan, individu dapat membangun hubungan yang khusus dengan Yang Ilahi. Ritus-ritus itu memberi jaminan akan hidup, kebebasan dan tanggung jawab atas nilai-nilai moral dalam masyarakat. Tidak hanya itu, agama juga berfungsi untuk menjalankan dan menegakkan serta memperkuat perasaan dan ide kolektif yang menjadi ciri persatuan masyarakat.

Dengan demikian menjadi jelas bahwa agama dapat menjadi kekuatan yang menyatukan masyarakat, bahkan jika terjadi banyak perbedaan antar individu atau golongan, apalagi jika terdapat artikulasi kepentingankepentingan yang membuahkan ideologi bersama. Dalam hal menyatukan masyarakat ritual-ritual keagamaan mempunyai tempat yang vital. Melalui 
ritual-ritual keagamaan individu-individu dalam masyarakat disatukan oleh kekuatan moral dan sentimen moral maupun sosial. Dengan berdasar pada pandangan Emile Durkheim di atas, dapatlah ditarik suatu benang merah bahwa, agama dengan segala ritual yang ada dan hidup serta yang dijalankan oleh para pemeluknya sesungguhnya dapat berdampak pada perubahan sosial dan membentuk tatanan masyarakat yang terintegrasi. Fenomena agama dalam dari perspektif Durkheim menjadi sangat positif yang mana melekatkan agama dengan penciptaan suatu masyarakat yang harmonis dan yang mengutamakan serta membangkitkan semangat kebersamaan dalam perkembangan dan perubahan kehidupan bermasyarakat, terutama bagi dunia kepemimpinan yang berkecimpung dalam ruang lingkup pendidikan.

\section{Kesimpulan}

Agama memang tidak dapat bertahan jika agama tidak berani menggaungkan suaranya dan mempunyai disposisi yang memihak masyarakat. Faktanya mayoritas masyarakat adalah orang biasa, 'tidak mempunyai kekuatan' yang didominasi oleh sekelompok kecil saja kalangan elit. Agama dengan demikian tidak dapat dipandang melulu sebagai tempat pelarian kaum terdesak dan akan hilang dengan membaiknya keadaan masyarakat dengan alasan:

Pertama, dari pengalaman gerakan keagamaan, di mana suatu wilayah kekuasaan hanya dihidupi oleh kaum elit atau masyarakat kelas atas, kita mengetahui bahwa justru agama adalah sumber motivasi dan kekuatan yang membebaskan orang dari keadaan tertindas menuju keadaan merdeka. Kecenderungan merosotnya penghayatan keagamaan dalam masyarakat mapan menjadi petunjuk bahwa agama harus senantiasa memperbaharui dan membenahi diri agar 'pesan kenabiannya' tetap dapat diterima masyarakat dari berbagai jaman. Agama dengan demikian menjadi sarana bagi tercapainya tujuan bersama suatu kelompok masyarakat (bonum commune).

Kedua, agama sebagai kekuatan pemersatu masyarakat justru amat dibutuhkan saat ini dimana nilai-nilai kolektivitas atau kebersamaan digerus bahkan dihancurkan oleh nilai-nilai individualis-pragmatis. Agama diperlukan bagi dunia kepemimpinan, agar masyarakat tidak terpecah belah dalam aneka kepentingan yang tidak dapat diartikulasikan bersama. Norma-norma dan nilai-nilai agama hendaknya dapat menjadi pegangan dan petunjuk bagi kehidupan bersama yang lebih harmonis. Lebih dari itu, agama hendaknya memelopori masyarakat yang terbuka terhadap perubahan. Sebab agama dan nilai-nilai sejati hanya dan justru akan mempertahankan diri apabila mampu menghadapi dan menyikapi perubahan sosial secara positif. 


\section{Daftar Pustaka}

Abdullah, M. Amin, Islamic Studies di Perguruan Tinggi: Pendekatan IntegratifInterkonektif, cet. ke-1, Yogyakarta: Pustaka Pelajar, 2006.

Armstrong, Karen, Kuasa dan Moral, Jakarta: Gramedia, 2001

Armstrong, Karen, Menalar Tuhan, Yogjakarta: Kanisius, 2006

Armstrong, Karen, Sejarah Tuhan, Bandung: Mizan, 1993.

Asmani, Jamal Ma'mur, Manajemen Pengelolaan dan Kepemimpinan Pendidikan Profesional, cet.ke-1, Ttp: Diva Press, 2009.

Elster, Jon, Marxisme: Analisis Kritis, terj. Sudarmaji, Jakarta: PT Prestasi Pustaka, 2000.

Fattah, Nanang, Landasan Manajemen Pendidikan, Bandung: Rosda Karya, 2008.

Faz, Ahmad Thoha, Titik Ba: Paradigma Revolusioner dalam Kehidupan dan Pembelajaran, cet. Ke-1, Bandung: PT Mizan Pustaka, 2007.

Hamilton, Malcolm B, The Sociology of Religion, London: Routledge, 1995.

Hatta, Mohammad, Ajaran Marx atau Kepintaran Sang Murid Membeo, cet. ke-1, Jakarta: Bulan Bintang, 1975.

Imam Muhni, Djuretna A, Moral dan Religi Menurut Emile Durkheim \& Henry Bergson, Yogyakarta: Kanisius, 1994.

Jurdi, Syarifuddin, Sosiologi Islam \& Masyarakat Modern: Teori, Fakta dan Aksi Sosial, cet. ke-2, Jakarta: Kencana Prenadamedia Group, 2014.

Kleden, Ignas, "Agama dan Perubahan Sosial", dalam LP3ES, Agama dan Tantangan Zaman, pilihan artikel Prisma 1975-1984, cet.ke-1, Jakarta: LP3ES, 1985.

Magnis-Suseno, Franz, Pemikiran Karl Marx dari Sosialisme Utopis ke Perselisihan Revisionisme, Jakarta: PT Gramedia Pustaka Utama, 2000.

Pidarto, Made, Manajemen Pendidikan Indonesia, Jakarta: Rineka Cipta, 2004.

Porter, Richard E. \& Lary A. Samoar dalam Deddy Mulyana, Jalaluddin Rakhmat, editor, Komunikasi Antar Budaya, Bandung: Remaja Rosdakarya, 2000.

Purwanto, Ngalim, Administrasi dan Supervisi Pendidikan, cet. ke-2, Bandung: PT. Remaja, 2010.

Sadari, et.al, "Reorientasi Nila-Nilai Kepemimpinan Lembaga Pendidikan Islam Muhammadiyah di Indonesia, dalam Fuaduna: Jurnal Kajian Keagamaan dan Kemasyarakatan, published by Institut Agama Islam Negeri (IAIN) Bukitinggi,Vol.03.No.1, 2019.

Sugiharto, I. Bambang, Wajah Baru Etika dan Agama, Yogjakarta: Kanisius, 2000.

Syahin, Abdus Shabur, Penciptaan Nabi Adam Mitos atau Realitas, terj. Abii Adam, Qishshah al-Khaliiqah, cet. ke-1, Yogyakarta: eLSAQ PRESS, 2004.

Syaodih S, Nana, Pengembangan Kurikulum Teori dan Praktik, Bandung: PT Remaja Rosdakarya, 2010.

Syari'ati, Ali, Kritik Islam atas Marxisme dan Sesat Pikir Barat Lainnya, terj. Marxism and Other Western Fallacies, cet. ke-1, Bandung: Mizan, 1983. 